\title{
O ciclo exoeritrocitário dos parasitos da malária (*)
}

\author{
por \\ W. Lobato Paraense \\ (Divisão de Estudos de Endemias) \\ (Com sete figuras no texto e três estampas) \\ No presente trabalho serão expostos, de maneira muito resumida, os \\ principais resultados dos estudos que estão sendo realizados por numerosos \\ pesquisadores sôbre o denominado "ciclo exoeritrocitário" dos plasmodídeos. \\ $\mathrm{O}$ autor não pretende ser completo em relação ao assunto, e as referências à \\ literatura só incluem algumas publicações escolhidas entre várias centenas até \\ hoje existentes sôbre a questão. Em monografia mais completa, que está sendo \\ elaborada e será divulgada na ocasião oportuna, será feito um estudo mais
} aprofundado do assunto em seus diferentes aspectos.

Segundo os conhecimentos correntes, os parasitos da malária evolvem em gerações alternantes. Um ciclo assexuado (esquizogonia) realiza-se no corpo do vertebrado, enquanto um ciclo sexuado (esporogonia) se processa no organismo do mosquito.

Quando um mosquito infectado alimenta-se de sangue, inocula sob a pele do individuo picado um pouco de saliva, que traz em suspensão certa quantidade de esporozoítas. Estes são lançados na circulação sanguinea, penetrando nas hemácias, no interior das quais mudam inteiramente de aspecto. De fusiformes que eram, tornam-se arredondados (esquizontes). Dai em diante realiza-se a reprodução assexuada.

Esta noção da penetração do esporozoíta na hemácia, que é transmitida por todos os tratados de parasitologia, deriva de um trabalho memorável de Schaudinn sôbre o Plasmodium vivax, publicado em 1903. As diferentes fases da penetração acham-se figuradas nesse trabalho, em desenhos coloridos feitos pelo próprio Schaudinn, que são comumente reproduzidos pelos tratados. A descrição dos sucessivos aspectos da penetração e do subseqüente

- Recebido para publicação a 23 de outubro e dado à publicidade em dezembro de 1944. 
desenvolvimento durante um periodo de 6 horas, em preparação observada ao microscópio, é tão minuciosa e verossímil que parece não haver dúvida sôbre a realidade do fenômeno. O esporozoíta alojou-se dentro da hemácia, adquir riu contôrno arredondado e vacúolo citoplasmático, e cresceu até ocupar $1 / 4$ do diâmerto do glóbulo, atingindo o estádio de esquizonte médio. Entretanto, por motivos inexplicáveis, tôdas as tentativas feitas posteriormente, por pesquisadores que buscavam confirmar a experiência de Schaudinn, resultaram em sistemático fracasso (YoRKe, 1931; Missiroli, 1933, 1934; Raffaele, 1934a, 1934b, 1936a; Kikuth, 1935; etc.). Também antes de Schaudinn, ensaios feitos no mesmo sentido haviam dado resultados negativos (Grassi, 1901; Ruge, 1901) .

Pouco antes de ser conhecido o trabalho de Schaudinn, foi expendida por Grassi (1901) uma idéia verdadeiramente luminosa para dar conta do destino imediato do esporozoíta ao ser inoculado no organismo humano. Observando diferenças morfológicas existentes entre esporozoítas e esquizontes, achava Grassi que êstes não derivavam diretamente daqueles. Segundo êle, os esporozoítas inoculados no organismo humano multiplicar-se-iam de maneira ainda não determinada, originando uma geração dotada de caracteres particulares que estaria relacionada com o início da incubação da malária. Observando-se o esquema dêsse autor, na sua monografia sôbre a malá ria (Est. 1, n. ${ }^{0} 2$ ?), compreende-se que a geração intermediária por êle suspeitada evolveria fora dos glóbulos vermelhos. Esta geração intermediária é que engendraria descendentes aptos a invadir as hemácias, já no fim da in. cubação.

De fato, a inoculação dos esporozoitas é seguida de um periodo de incubação mais ou menos longo, durante o qual não se encontram parasitos no sangue periférico. Terminada a incubação, os parasitos são achados mais ou menos fàcilmente nos exames de sangue.

Sôbre o que se passa durante a incubação, diz-se geralmente que as prir meiras hemácias, infectadas de acôrdo com as observações de ScHaudinN (pela penetração dos esporozoitas) dirigem -se para os órgãos profundos, prin cipalmente o baço, em cujos capilares se acumulam. Aí então se reproduzem dentro dos glóbulos vermelhos, até atingirem um número suficiente para invadir a circulação geral e desencadear o acesso febril característico. Entretanto, a investigação rigorosa demonstra que durante a incubação não existem hemácias parasitadas em parte alguma. A transmissão da malária por inoculação de sangue, durante a incubação, já foi tentada numerosas vêzes, por muitos investigadores, tanto no homem como nas aves, nunca tendo sido coroada de êxito (Boyd \& Thomas, 1934; Kikuth, 1935; Raffaele, 1936a, 


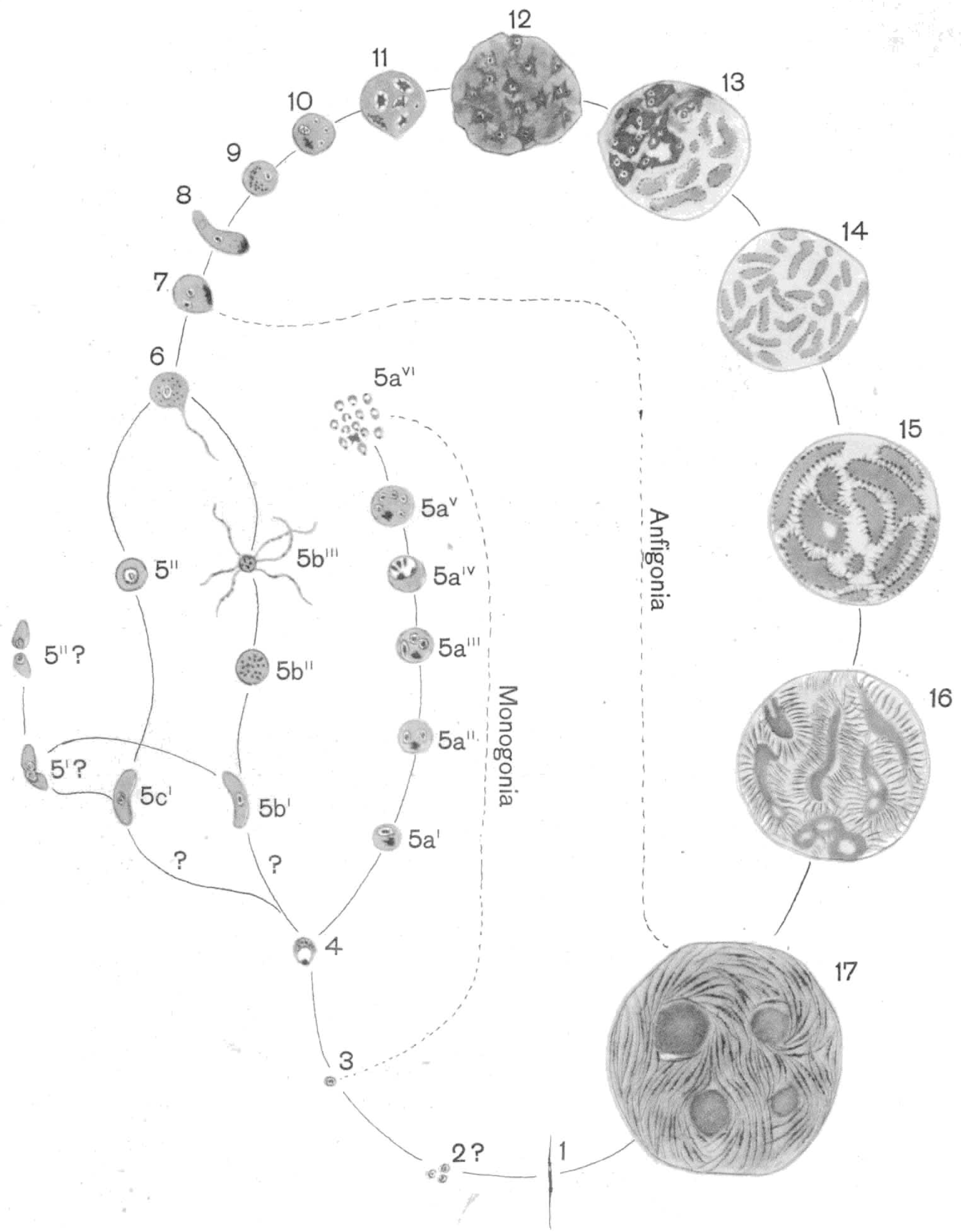

Evolução do parasito da malária, segundo Grassi.

Em 2? está representada a suposta divisão do esporozoíto (1), que produzirá elementos (3) infectantes para as hematias.

Em 5'? e 5"? acha-se figurada a divisằo partenogenética dos gametocitos, também imaginada pelo autor.

W. L. Paraense: O ciclo exoeritrocitário 


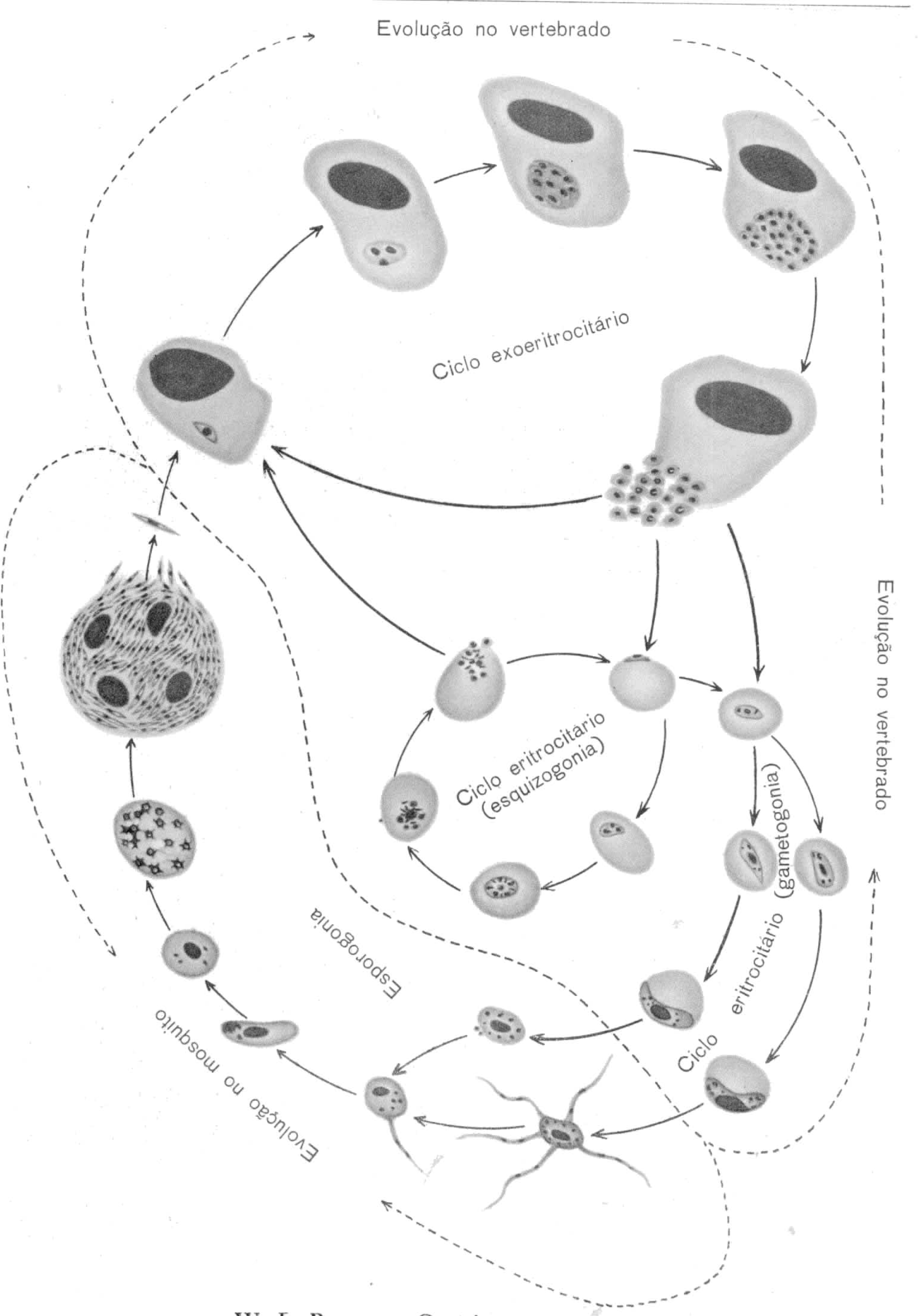

W. L. Paraense : O ciclo exoeritrocitário. 


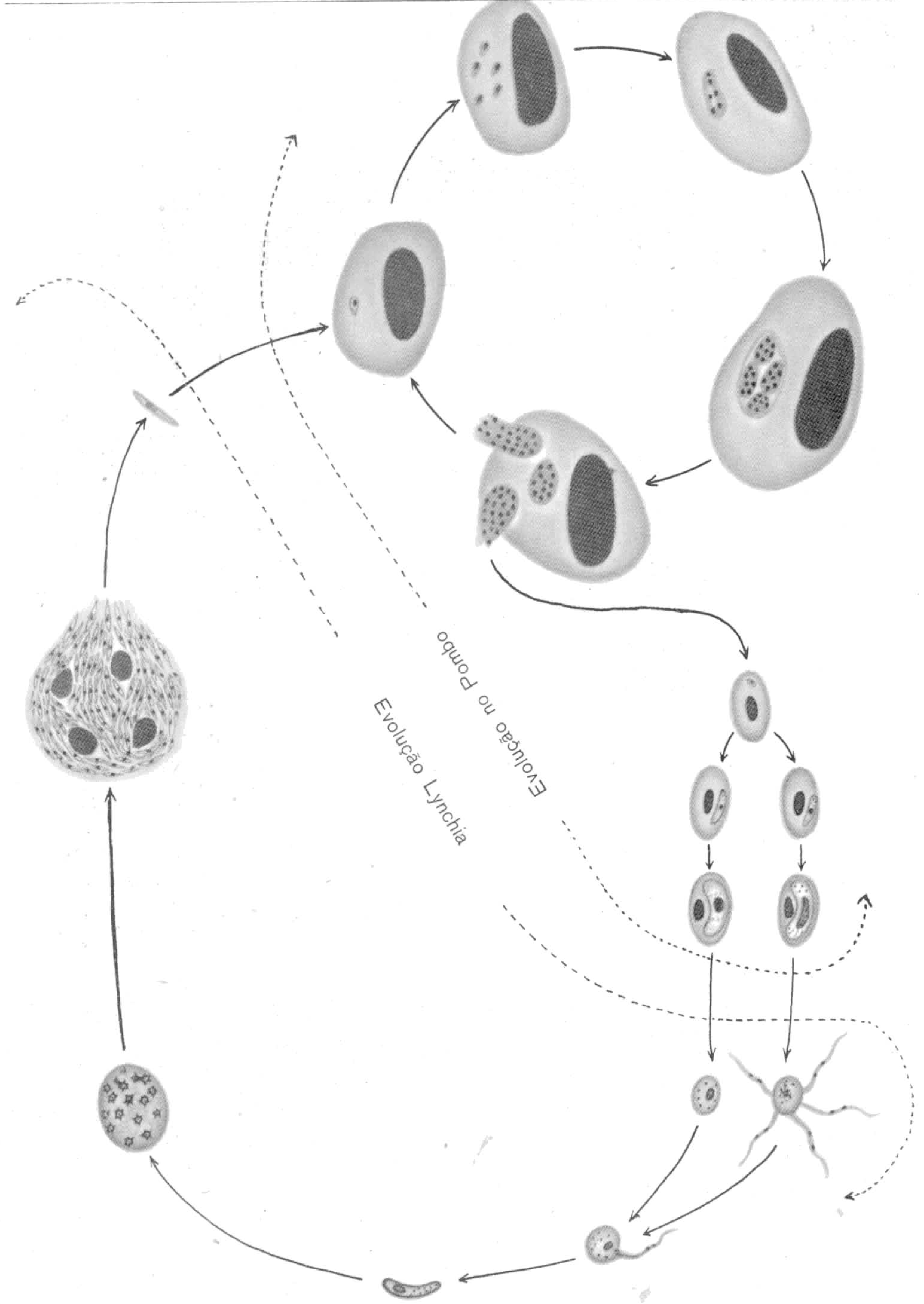

W. L. Paraense : O ciclo exoeritrocitário.

Ciclo evolutivo do Haemoproteus columbae 
1937b; Ciuca $\mathcal{E}$ col., 1937; Missiroli, 1937; Warren E Coggeshall, 1937; Boyd $\mathcal{E}$ Matthews, 1939; etc.) .

Tôdas essas experincias negativas de inoculação de sangue denunciam a invalidade das noções correntes sôbre o que se passa durante o periodo de incubação da malária. A explicação é dada pela recente doutrina do ciclo exoeritrocitário dos plasmodídeos, que vem evolvendo cada vez mais sòlidamente de alguns anos para cá.

Em 1931, JAMEs apresentou os resultados gerais da prática da malarioterapia durante vários anos em alguns milhares de doentes de paralisia geral por êle tratados na Inglaterra. Entre múltiplos assuntos, comentava as diferenças dos resultados obtidos no tratamento da malária terapêutica, segundo a transmissão da mesma era feita por meio de sangue parasitado ou de esporozoítas. Quando se tornava necessária a ação do quinino, para sustar os acessos da malária, o medicamento era mais efeciente nos casos inoculados com sangue do que nos picados por mosquitos. Nestes últimos, além disso, eram mais comuns as recaidas, que se observavam em cêrca de $50 \%$ dos casos. Também nos inoculados com esporozoitas a quinino era ineficaz para evitar a multiplicação parasitária, isto é, não agia como profilático.

Para explicar essas diferenças emitiu JAMEs duas hipóteses. A primeira foi que os esporozoitas, em vez de penetrarem nos glóbulos vermelhos, entrariam nas células do tecido conjuntivo ou nas que revestem os capilares sanguíneos, aí permanecendo até à rotura destas células, algum tempo depois .

Esta hipótese também explicaria o fato, algumas vêzes observado por JAMES, de que indivíduos inoculados com esporozoítas apresentavam prolongadíssima incubação, chegando mesmo até a vários meses. (Casos de incubação muito longa são referidos na bibliografia deste há muito tempo; ver MARChiafava \& Bignami, 1931, pg. 124). A segunda hipótese foi que os esporozoítas, por terem extremidades afiladas, penetrariam no corpo das hemácias. onde ficariam abrigados contra a ação do quinino; ao passo que os merozoítas, por terem contornos arredondados, não seriam capazes de penetrar nos glóbulos, ficando acolados à periferia e sujeitos à atividade medicamentosa.

A primeira dessas hipóteses parece corresponder à realidade dos fatos, achando-se em grande parte confirmada.

Efetivamente, poucos anos mais tarde começaram a ser evidenciados aspectos parasitários até então desconhecidos, em casos de malária das aves. Nestes casos eram encontrados os plasmódios habitualmente existentes nos glóbulos vermelhos, caracterizados pela presença de pigmento. Mas ao lado 
dêles existiam também parasitos em esquizogonia, desprovidos de pigmento, de tamanho bem maior, cujas formas maduras possuiam maior número de núcleos e cujo caráter mais saliente era a localização no interior das células retículo-endoteliais. Estas esquizogonias apigmentadas foram sucessivamente observadas em várias espécies de plasmódios de aves, do homem e de sáurios: P. elongatum (Huff \& Bloom, 1935; Rafanele, 1936b); P. praecox (RafFaele, 1936c); $P$. gallinaceum (James $\&$ TAte, 1937a, 1937b); $P$. vivax (RAffaele, 1937c); P. falciparum, durante a incubação (RAfFaele, 1938a), durante a fase aguda (Paraense \& Silva, 1941; Galvão, 1941) e na infecção crônica (CASINI, 1939); P. malariae (RAfFAele, 1940); P. cathemerium (Kikuth \& Mudrow, 1937); $P$. circumflexum (Manwell, E Goldstein, 1938, 1939); P. nucleophilum (Hegner E Wolfson, 1938a, 1938b); P. juxtanucleate (Barreto, 1943); P. dutae (Simpson, 1944); P. mexicanum (Thompson \& HuFF, 1944).

Esstes achados eram extremamente significativos, porque até então sabia-se que os plasmódios, evolvendo nos vertebrados, não eram capazes de infectar outros elementos além dos glóbulos vermelhos. Tomando como exemplo as considerações de Brumpt, no seu Précis de Parasitologie (1936), aí encontramos, a respeito dos plasmodídeos (pág. 402):

"Esta familia é a mais bem conhecida da subordem dos Hemosporídeos. Os parasitos que a compõem são amebóides, vivem nas hemácias do homem ou dos animais de sangue quente ou frio, e produzem pigmento negro denominado hemozoina. Sua reprodução se faz, como a dos Coccídeos, por esquizogonia e por esporogonia. Todos os seus estádios evolutivos no vertebrado se encontram nas hemácias."

Os grifos, que pertencem ao próprio BRUMPT, fazem sobressair a importáncia de certos elementos na caracterização dos plasmódios: formação de pigmento e evolução exclusivamente eritrocitária, no hospedeiro vertebrado. Pois bem: os achados há pouco referidos estavam demonstrando que os plasmódios não só podem evolver em outros elementos além das hemácias, como também ao evolver nessas outras células não produzem pigmento negro. Isto explica-se muito fàcilmente: o pigmento é elaborado à custa da hemoglobina, que não existe na célula retículo-endotelial.

A teoria do ciclo exoeritrocitário ainda não atingiu a forma definitiva, o que é natural num assunto cujo estudo foi iniciado há tão pouco tempo. Entretanto, ela já possui elementos definidos de valor suficiente para erigir um 
arcabouço de doutrina. Tentarei resumir em seguida os fatos elementares que permitem construir essa teoria, em um esquema que naturalmente está sujeito a ligeiras variações dependentes das opiniões individuais (Est. 2) .

Os esporozoítas, inoculados pelo mosquito, multiplicam-se inicialmente no ponto de inoculação (Missiroli, 1933, 1934; Kikuth E Mudrow, 1938b, 1940; Mudrow, 1940; Schulemann, 1942; Paraense, 1943; Reichenow \& Mudrow, 1943). É possível que parte dêles seja arrastada pela corrente san-

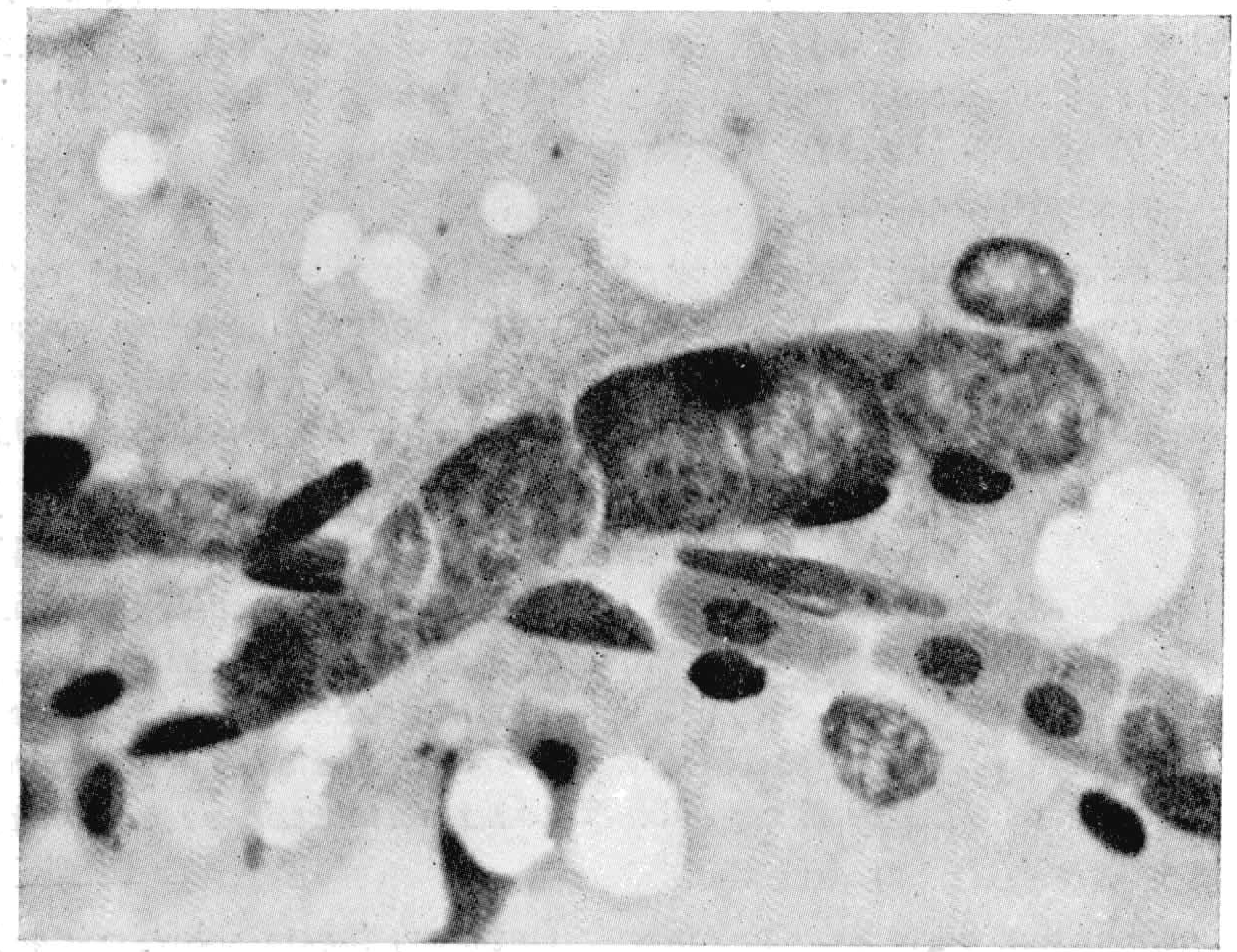

Fig. $1-P$. gallinaceum. Esquizogonia exoeritrocitária. Estádios pouco adiantados nos quais o protoplasma dos parasitos se cora intensamente de azul e os núcleos ainda não estão bem individualizados.

guínea para os órgãos profundos, ou siga mais lentamente pelos trajetos linfáticos (Missiroli, 1937; Boyd \& Kitchen, 1939). As fases mais precoces dessa multiplicação ainda são muito duvidosas, mas estão sendo intensamente pesquisadas. Depois de algum tempo, cêrca de 3 dias, são vistos em quantidade relativamente grande, no ponto de inoculação, elementos semelhantes às formas exoeritrocitárias, dentro de células retículo-endoteliais do tecido subcutâneo (PARAENSE, 1943). Êstes elementos derivam seguramente dos esporozoítas . 
Depois de darem origem a várias gerações sucessivas no ponto de inoculação, tais elementos assumem uma distribuição mais geral, disseminandose pelo sistema retículo-endotelial. De fato, na segunda metade do periodo de incubação êles já podem ser encontrados em pequena quantidade no interior das células retículo endoteliais do fígado, do encéfalo, do baço e da medula óssea (Kikuth \& Mlidrow, 1937, 1938b; Shortt, Menon \& Iyer, 1940; Iyer, Shortt $\mathcal{E}$ Menon. 1941; etc.), onde também já se encontram elementos derivados da multiplicação dos esporozoítas que foram levados a êsses órgãos pelas vias sanguinea e linfática.

Os parasitos exoeritrocitários multiplicam-se dentro das células retículoendoteliais, dando esquizogonias apigmentadas volumosas (figs. 1, 2, 3 e 4) que crescem até romperem as células que as abrigam (fig. 5). São assim libertados numerosos corpúsculos semelhantes aos merozoítas do ciclo pigmentado, os quais penetram em outras células retículo-endoteliais. São os denominados merozoítas exoeritrocitários, que vão reiniciar novo ciclo apigmentado. Depois de certo número de gerações dessa natureza, e coincidindo com o fim da incubação, os merozoitas exoeritrocitários tomam um entre dois destinos: A maior parte dêles cai na circulação sanguínea, invadindo os glóbulos vermelhos para realizar o conhecidíssimo ciclo pigmentado (fig. 7), enquanto uma parte continua a parasitar a célula reticulo-endotelial, provocando as recaidas e a cronicidade e resistindo à ação da terapêutica (fig. 6).

Inicialmente, acreditou-se que sòmente os esporozoitas eram capazes de desenvolver o ciclo exoeritrocitário (RAfFaEle. 1936b, 1936c), e, assim, julgava-se que os parasitos, uma vez passando a evolver nos glóbulos vermelhos, não poderiam voltar às células retículo-endoteliais (RAfFaele, 1938b). Depois apareceram observações referindo o encontro de esquizogonias exoeritrocitárias em animais inoculados com sangue em vez de esporozoítas (RAfraele, 1937a; Kikuth, 1937; Kikuth \& Mudrow, 1938a; Corradetti, 1938; Chortis, 1938; JAmEs, 1939, etc.). A explicação mais plausivel para esta complicação foi logo apresentada: no sangue circulante existem representantes do sistema retículo-endotelial, os monócitos, que podem aparecer parasitados por esquizontes exoeritrocitários, e além disso êstes esquizontes podem ser lançados na corrente sanguínea pelas células endoteliais que os abrigam. Os monócitos parasitados, ou os esquizontes exoeritrocitários libertados no sangue, uma vez inoculados dariam as formas exoeritrocitárias encontradas nos novos animais (Rafraele, 1937a, 1938b). Porém sabe-se hoje que os parasitos dos glóbulos vermelhos, pelo menos em certas espécies de plasmódios, podem voltar a evolver nas células retículo-endoteliais. Tal fato foi induzido por JAMEs (1939) para explicar os resultados dos seus trabalhos com $P$. gallinaceum, sendo em seguida comprovado por Coulston \& MANwell (1940, 
1941). Êstes autores, inoculando uma única hemácia parasitada pelo $P$. circumflexum, retirada do sangue com micropipeta, obtiveram uma infecção muito leve, com parasitismo exclusivamente sanguíneo. Porém depois de algumas passagens apareceram as formas exoeritrocitárias à medida que a infecção se ia agravando por inoculações sucessivas.

Parece, entretanto, que o regresso dos plasmódios dos glóbulos verme lhos ao retículo-endotelio só se verifica raramente na malária humana. $\mathrm{Na}$ prática da malarioterapia observa-se que, em geral, as infecções induzidas por

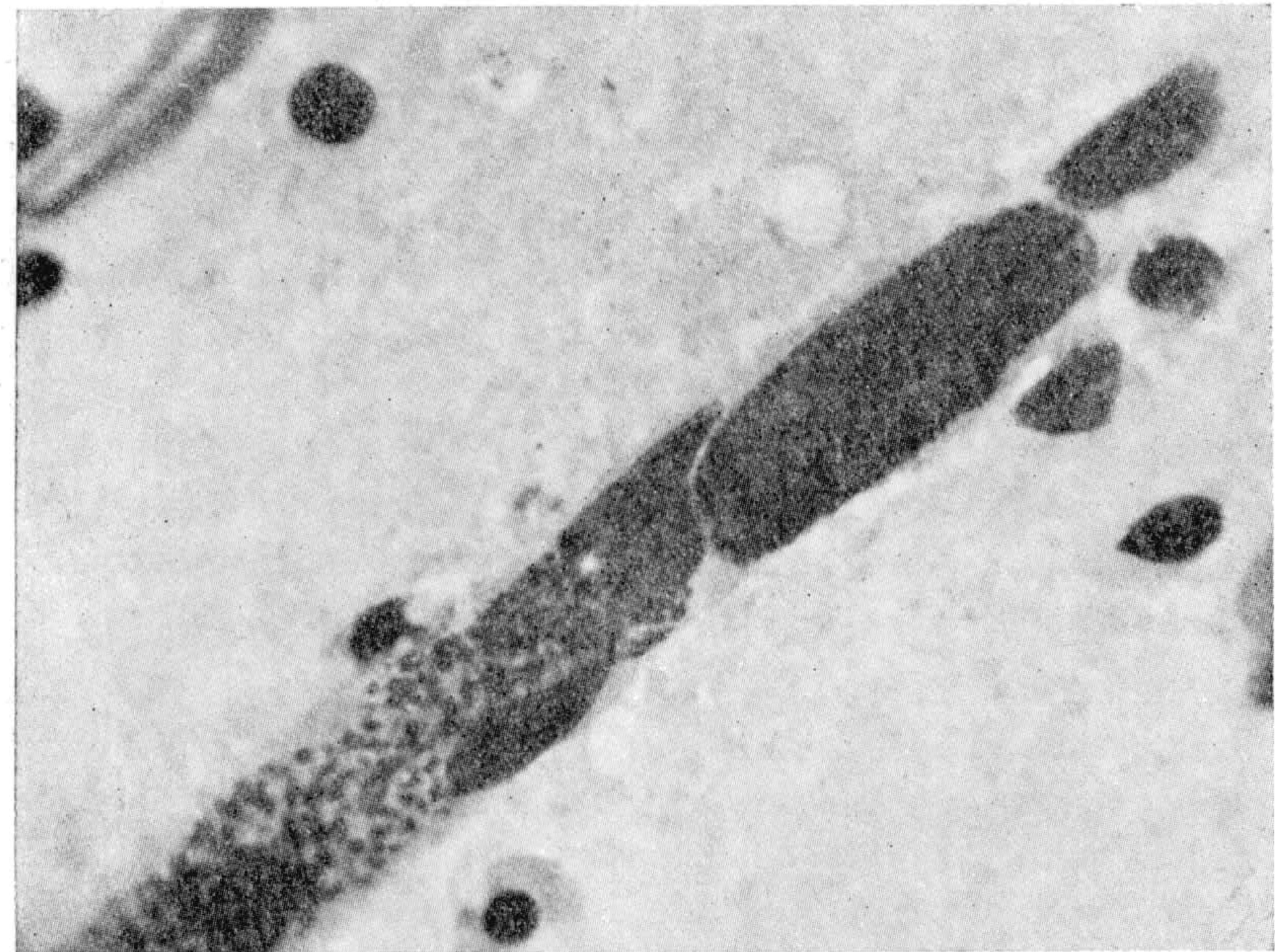

Fig. 2 - Estádio mais evolvido. Massas esquizogônicas mais volumosas que as da fig. anterior, observando-se tendência à individualização dos merozoitas.

meio de sangue parasitado são fàcilmente evitáveis e curáveis pelo quinino, não dão recaídas e evolvem mais benignamente do que os casos infectados por esporozoítas, sendo mesmo comuns as curas espontâneas. Estas constatações sugerem a ausência de formas exoeritrocitárias no organismo.

A noção do ciclo exoeritrocitário representa um conceito revolucionário apenas para aquêles que se colocam no pôsto de observação exclusivo ao campo da malária. Entretanto, nada mais natural que admiti-la para quem compara, sob o ponto de vista evolucionístico, a biologia do plasmódio com 
a dos outros parasitos afins. A maior parte dos hematozoários fêz a sua adaptação à vida parasitária dentro de células do sistema retículo-endotelial. De todos êles, apenas os babesídeos ainda não revelaram possuir um ciclo assexuado em células daquele sistema, não sendo improvável que tal ciclo ainda venha a ser encontrado.

O ciclo exoeritrocitário dos plasmódios assemelha-se estreitamente à evolução esquizogônica dos hemoproteídeos, descrita por ArAgão (1907, 1908a, 1908b) para o Haemoproteus columbae. Neste caso os esporozoitas, inoculados pela línchia, penetram em células do retículo-endotélio, multiplicando-se por esquizogonia nos elementos endoteliais do pulmão. Formamse assim merozoitas semelhantes aos do ciclo exoeritrocitário, que são lançados na circulação sanguinea. Aqui chegados, não realizam a esquizogonia eritrocitária, como fazem os plasmódios, transformando-se, porém, diretamente em gametócitos. De modo que a ausência de esquizogonia dos hemoproteídeos nos glóbulos vermelhos fica sendo o único fato que permite disr tingui-los dos plasmodídeos. A existência do ciclo exoeritrocitário aproxima essas duas famílias, tornando menos profunda a demarcação entre elas (Es tampa 3).

Muitos argumentos têm sido dirigidos contra a teoria do ciclo exoeritrocitário. Dentre tôdas as opiniões contrárias, a mais interessante parece ser aquela que considera os elementos exoeritrocitários como alheios ao ciclo do parasito da malária. Tratar-se-ia de infecções mistas. $\mathrm{Na}$ monografia de Hewitr (1940) sôbre a malária aviária, são enumerados os pontos principais nos quais se baseiam as opiniões favoráveis à infecção mista (pg. 179). Entretanto já foram feitas várias tentativas para separar o plasmódio do possivel parasito associado, nada se tendo ainda conseguido (Кікuтн $\mathcal{E}$ Mudrow, 1938b; Hegner \& Woi.fson, 1938b, 1939). Nunca foi assinalado o encontro de qualquer coisa semelhante às formas exoeritrocitárias nos capilares do cérebro de aves livres de malária. No decurso dos meus trabalhos, as formas exoeritrocitárias aparecem em animais nascidos e criados no laboratório, ao abrigo de contaminações tanto quanto possivel, e infecr tados por picada de mosquitos também nascidos no laboratório e cujas glândulas salivares só contêm esporozoitas de determinada espécie de plasmó dio. Finalmente, no ponto de inoculação dos esporozoítas desenvolvem-se esquizogonias exoeritrocitárias típicas (KIKuTH \& Mudrow, 1938b, 1940; Mudrow, 1940; Paraense, 1943; Reichenow \& Mudrow, 1943).

$\mathrm{O}$ aspecto morfológico dos elementos exoeritrocitários é o mesmo em tôdas as espécies de plasmódios nas quais êsses elementos têm sido observados. Esta semelhança é um dos fatos que parecem apoiar a idéia da infecção mista, mas não constitui sólido argumento para o fim proposto. Basta 
lembrar a semelhança existente entre os esquizontes jovens (trofozoítas) eritrocitários de todos os plasmódios aviários, não obstante pertencerem a espécies diferentes. Lembrarei ainda que a morfologia dos elementos evolutivos de um plasmódio no mosquito é tão semelhante em tôdas as espécies nas quais esta evolução é conhecida, que ninguém poderá dizer de que espécie se trata pela simples observação dos aspectos morfológicos. Segundo Boyd (1935) o critério morfológico é elemento inseguro para a identificação das espécies de esporozoítas.

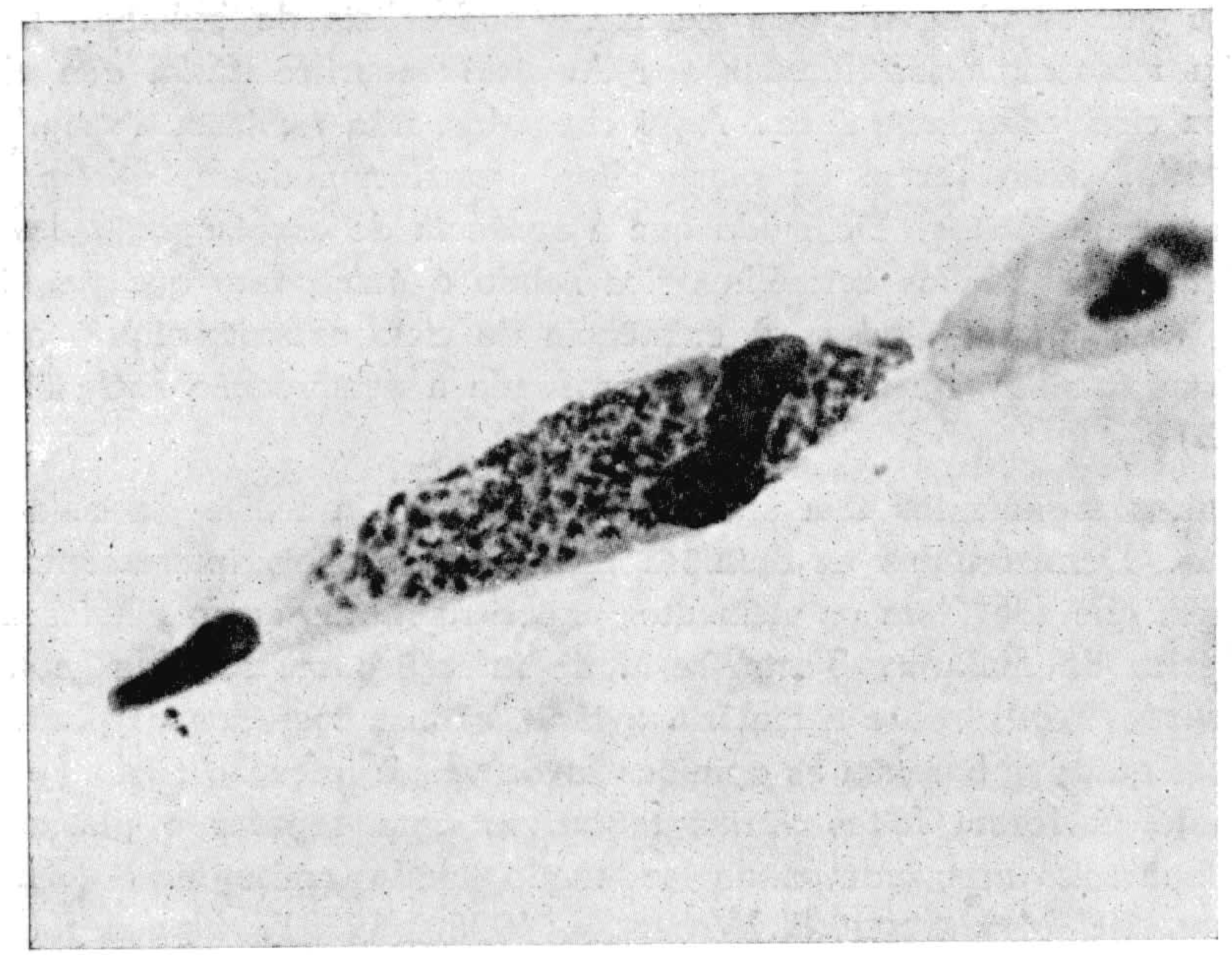

Fig. 3 -- Volumoso esquizonte quase maduro.

O ciclo exoeritrocitário ainda não foi assinalado em tôdas as espécies de plasmódios. Entretanto, para que êle tenha validade, não é necessário que compareça em tôdas as espécies. Entre os tripanosomas, observa-se que algumas espécies histotrópicas são capazes de evoluir no retículo-endotélio sob a forma de leishmânias, enquanto outras espécies não possuem esta propriedade. Se o mesmo acontecer entre os plasmódios, em relação ao ciclo exoeritrocitário, a conseqüência será reduzir a extensão da noção do referido ciclo, e distinguir espécies capazes e incapazes de evolver no retículo-endotélio. Entretanto acredito que o fato de não ser ainda conhecido êste ciclo em tôdas as espécies de plasmódios deve ser explicado antes por deficiências 
do método empregado para a sua pesquisa. Relativamente à formação dos elementos exoeritrocitários, existem certas diferenças de comportamento entre as várias espécies de plasmódios.

É assim que o $P$. praecox, inoculado sob a forma de esporozoita, dá esquizontes exoeritrocitários durante a incubação e depois êstes esquizontes vão passando para as hemácias, esgotando-se depressa os mananciais primitivos do retículo-endotélio. Tanto que, depois de iniciada a infecção sanguínea, é dificilimo o encontro dos parasitos exoeritrocitários. Se o ciclo exoeritrocitário aqui é rápido, e os seus elementos se esgotam à medida que incrementa a infecção do sangue, devem êstes ser procurados de preferência nas últimas horas do periodo de incubação, quando, conforme tudo faz supor, serão seguramente encontrados. Aliás, no hemoproteu do pombo, cujo ciclo retículo-endotelial é indiscutível e universalmente aceito depois dos trabalhos de Aragão, acontece coisa semelhante. Muitas vêzes é pràticamente impossivel o encontro de formas retículo-endoteliais em pombos com infecção sanguínea bastante intensa.

O P. gallinaceum e o $P$. cathemerium dão formas exoeritrocitárias durante a incubação, que depois são parcialmente lançadas no sangue, permanecendo outra parte como um resíduo no retículo-endotélio. Aqui os parasitos exoeritrocitários podem ser encontrados ao lado dos parasitos sanguineos em qualquer periodo da infecção.

$O P$. elongatum forma esquizontes exoritrocitários que também persistem durante tôda a infecção, predominando de maneira notável sôbre os parasitos sanguineos. Aqui acontecem dois fatos interessantes: a divisão esquizogônica dos parasitos pigmentados tem lugar nos capilares das visceras, como no $P$. falciparum; e as formas encontradas no sangue periférico são trofozoitas e grande abundância de gametócitos, como nos hemoproteus.

As quatro espécies aviárias referidas são as mais bem estudadas sob o ponto de vista do ciclo exoeritrocitário. Além delas, também foram assinaladas formas retículo-endoteliais no $P$. circumflexum, $P$. nucleophilum, $P$. juxtanucleare e $P$. durae, não tendo sido ainda encontradas nas seguintes espécies: $P$. hexamerium, $P$. lophurae, $P$. lutzi, $P$. oti, $P$. paddae, $P$. polare, $P$. rouxi, $P$. subpraecox e $P$. vaughani. Julgo digno de atenção o fato de que em tôdas estas últimas espécies, com excepção de $P$. rouxi e $P$. subpraecox. é inteiramente desconhecida a evolução no mosquito. É muito provável que apareçam as formas exoeritrocitárias quando se conseguir a transmissão por meio de esporozoítas. Em cinco das oito espécies portadoras de formas exoeritrocitárias é conhecida a evolução no mosquito, faltando determinar esta evolução no $P$. durae, $P$. juxtanucleare e $P$. nucleophilum. As duas últimas espécies só revelaram o ciclo exoeritrocitário nas mãos de BARRETo (1943) e de Hegner \& Wolfson (1938a, 1938b), respectivamente, assim mesmo de 
modo escasso, não tendo sido êste ciclo observado por outros pesquisadores. O $P$. durae, ainda pouco estudado, parece ter um comportamento semelhan te ao do $P$. gallinaceum. Quanto a $P$. subpraecox e $P$. rouxi, não é de meu conhecimento qualquer trabalho em que estas espécies sejam estudadas sob o ponto de vista da esquizogonia exoeritrocitária. Para se afirmar, portanto, a ausência absoluta de esquizogonias retículo-endoteliais numa determinada espécie de plasmódio, é preciso provocar-se a infecção não só por inoculação de sangue como também por picada de mosquito, e pesquisá-la em tôdas as fases da infecção do vertebrado.

A seguir passarei em revista alguns dos problemas de malariologia que encontram solução quando reduzidos aos têrmos da teoria exoeritrocitária.

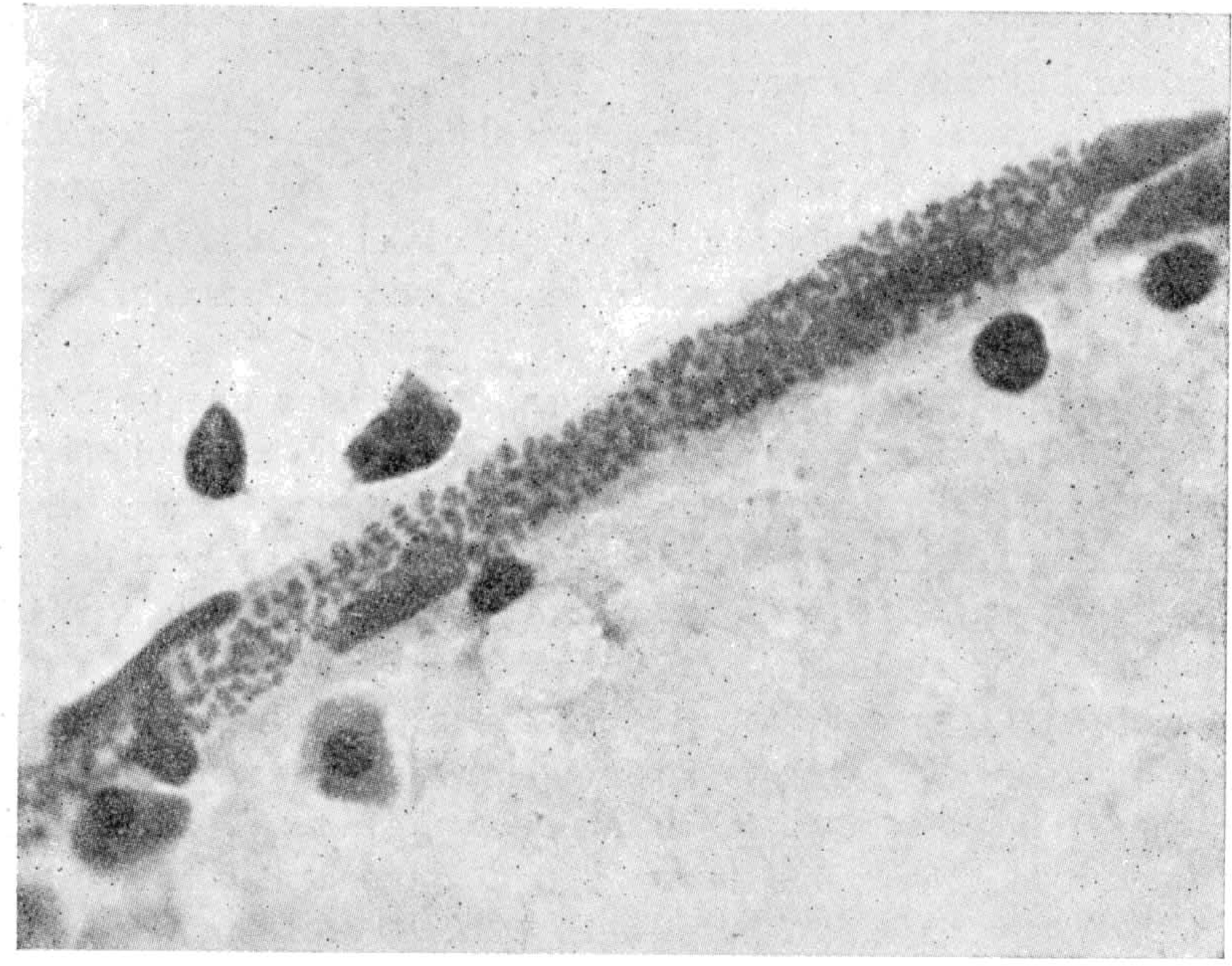

Fig. 4 - Merozoitas maduros bem caracterizados pelo aspecto do núcleo em ferradura ou em anel. Nesta fig. e nas três precedentes vê-se como as células endoteliais estão intensamente bloqueadas pelos parasitos.

Já foi visto como os fatos observados no período de incubação podem ser claramente compreendidos de acôrdo com esta teoria.

Outro fato que nunca foi satisfatòriamente explicado em função dos postulados clássicos é o da ineficácia dos medicamentos profiláticos usuais. Se de um lado existem os que acreditam na ação preventiva dos antimalári- 
cos conhecidos, muitos outros duvidam de tal ação ou negam -na inteiramente, baseados nos resultados da experimentação. Muitos ensaios feitos sôbre o homem, utilizando o quinino antes da inoculação de esporozoítas e continuando a aplicação do medicamento durante muitos dias após a inoculação, têm demonstrado que o poder infeccioso do esporozoíta não é aniquilado. Os pacientes apresentam a malária depois de uma incubação um tanto mais longa, e muitas vêzes após incubação normal. Quase sempre a sintomatolo-

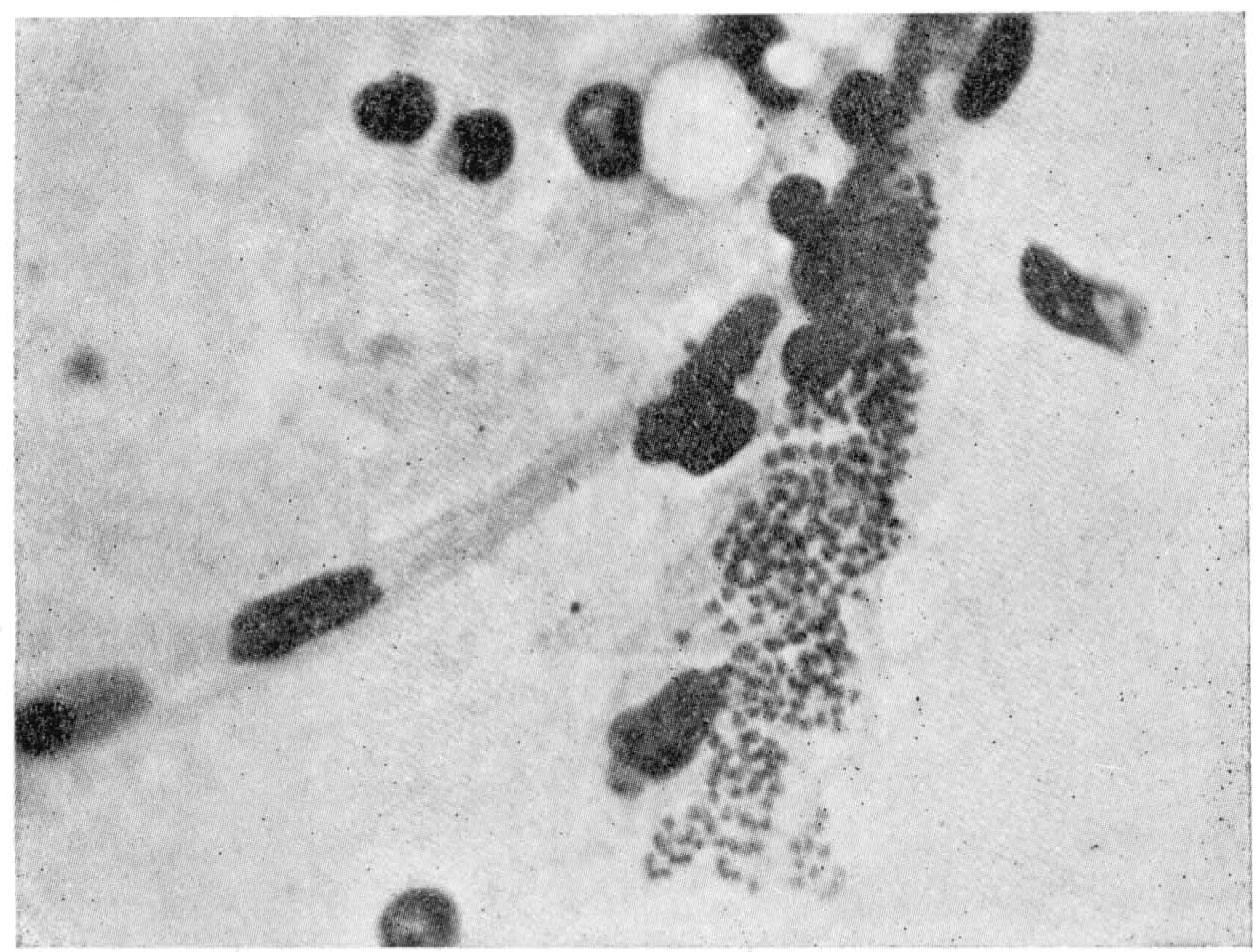

Fig. 5 - A tração exercida durante a confeç̧ão do preparado provocou a rotura de uma célula endotelial, libertando inúmeros merozoitas maduros.

gia é atípica, sendo os parasitos encontrados em quantidade ínfima no sangue e podendo persistir ou desaparecer juntamente com os sintomas, para reaparecer mais tarde, em intermitências irregulares. Enquanto dura a adminis tração do quinino êstes surtos se repetem de maneira periódica até que, suspenso o medicamento, a malária muitas vêzes se revela claramente (JAMEs, 1931 ).

No paludismo aviário também se depara o experimentador com a mesma ineficácia do quinino e da atebrina para prevenir a reprodução do plasmódio. Interrompida a profilaxia medicamentosa, aparece a infecção. Parece que a plasmoquina possui uma ação profilática mais nítida, porém esta geralmente só se faz sentir em dose mais alta do que a tolerada normalmente pelo organismo. 
Ao contrário do que ficou exposto, a administração do quinino previne fàcilmente o aparecimento da malária em indivíduos inoculados com sangue parasitado (JAMES, 1931).

Se encararmos os dados da questão pelo ponto de vista da teoria exoeritrocitária, concluiremos sem dificuldade que a ação dos antimaláricos cor nhecidos só se exerce contra os parasitos que evolvem no sangue. Os esporozoitas nada sofrem, em primeiro lugar porque certamente oferecem resistência a êsses medicamentos, e em seguida porque assumem localização in-

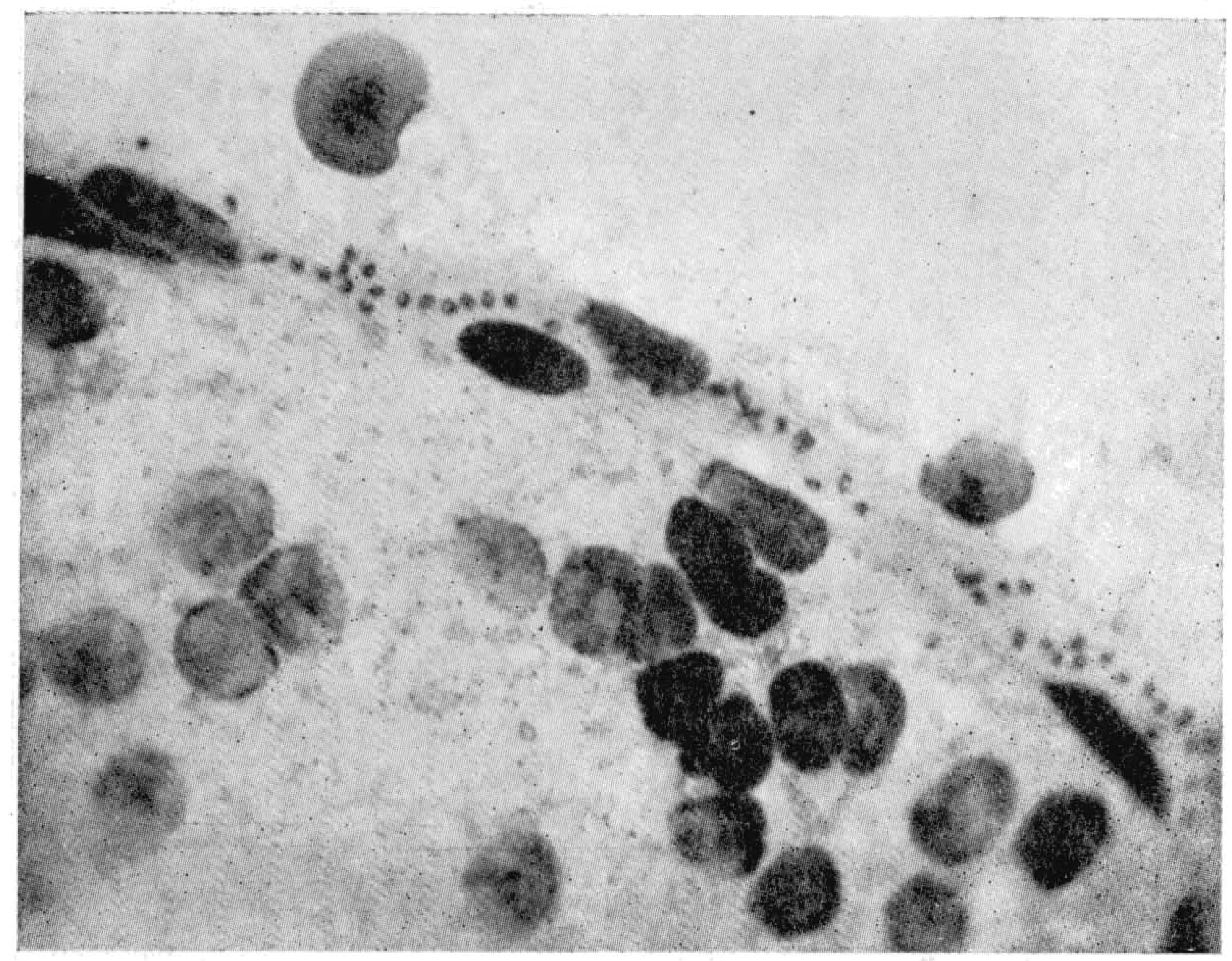

Fig. 6 - Elementos encontrados em um caso tratado durante 20 dias

tracelular, no interior dos elementos retículo-endoteliais. Aí acantonados, vão êles realizar a sua evolução exoeritrocitária, ao abrigo do agente terapêutico, e só depois que os seus descendentes passam a parasitar as hemácias pode o tratamento surtir efeito.

A ineficácia do quinino contra os elementos exoeritrocitários é fato que tenho verificado sempre que o tenho pôsto à prova. Além disso, é claramente demonstrado pela seguinte experiência de Adler \& TCHernomoretz (1941), que tenho repetido numerosas vêzes com resultados idênticos:

Um pequeno lote de galinhas foi inoculado com sangue portador de $P$. gallinaceum. Ao aparecerem os primeiros parasitos sanguíneos, os animais foram tratados intensivamente com o cloridrato de quinino (150 mg por 
quilo), desaparecendo por completo os plasmódios dos glóbulos vermelhos. Os órgãos dêstes animais, entretanto, apresentaram esquizontes exoeritrocitários, e foram inoculados em novas aves. No dia seguinte ao da inoculação estas últimas começaram a receber altas doses de quinino. Apesar do tratamento intensivo, apareceram pequenos trofozoítas nos glóbulos vermelhos, resultantes sem nenhuma dúvida dos esquizontes exoeritrocitários. Êstes trofozoitas, entretanto, nem chegavam a crescer, perecendo ràpidamente sob o efeito da medicação. Ainda aqui, apesar de negativo o sangue, existiam numerosos esquizontes exoeritrocitários nas vísceras. A inoculação dêstes órgãos em aves também quininizadas deu resultado idêntico, e o mesmo reproduziu-se em cinco passagens sucessivas, quando a experiência foi encerrada. Como se vê, o quinino em nada afeta o desenvolvimento dos parasitos exoeritrocitários, e uma vez que êstes são os únicos existentes durante a incubação, resta-nos aguardar a descoberta de um agente terapêutico eficaz contra êles para podermos falar na solução do problema da profilaxia medir camentosa do paludismo.

Outro problema ainda insolúvel é o das recaídas da malária. Não obstante a ação do quinino e da atebrina sôbre os parasitos pigmentados assexuados ser coisa verificada, nem sempre se consegue na malária de primeira invasão uma cura verdadeiramente radical, sem que seja seguida de uma ou mais recaídas. Aqui acontece o mesmo que foi referido a respeito da profilaxia: a malária induzida com esporozoitas e tratada com o quinino apresenta no mínimo $50 \%$ de recaídas, ao passo que estas são pouquíssimo freqüentes quando se inocula sangue parasitado (James, 1931). Cabem ao caso argumentos idênticos aos emitidos a respeito da profilaxia medicamentosa. Os parasitos que, ao fim da incubação, permanecem residualmente no retículo-endotélic, não são atacados pelos medicamentos conhecidos, parecendo mesmo que êstes medicamentos dificultam a passagem dos esquizontes exoeritrocitários para o sangue. Pelo menos é o que tenho observado com o $P$. gallinaceum: a administração de quinino faz desaparecer completamente os parasitos assexuados sanguíneos, e se o tratamento é mantido e o animal sacrificado, encontram-se as células retículo-endoteliais repletas de esquizogonias exoeritrocitárias em quantidade excessivamente maior que nos animais de contrôle. As figuras 1-6 correspondem a preparados de cérebro de pintos tratados intensivamente com o cloridrato de quinino. $O$ mesmo observou RafFaele (1938b) em infeç̧ões tratadas com atebrina. É de supor que no homem aconteça coisa semelhante. Numerosas observações, que parece não terem sido levadas na devida conta, têm demonstrado que a malária inoculada por picada de mosquito e tratada intensivamente logo ao aparecimento dos primeiros sintomas, é bastante fértil em recaídas. 
Esta questão das recaídas já foi encarada de várias maneiras. Durante muito tempo julgou se que eram causadas pela partenogênese dos gametór citos fêmeos, de acôrdo com a suposição de Grassi (Est. 1, ns. 5'? e 5"?) expendida nos seus Studi di un zoologo sulla malaria e com sucessivas obser vações dos velhos pesquisadores (Ziemann, 1906; Maurer, 1902; PitTALUGA, 1903; etc.). A noção da partenogênese, entretanto, foi definitivamente firmada em conseqüência dos trabalhos de Schaudinn (1903). Baseando-se na sua observação, dizia êste autor que os macrogametócitos do $P$. vivax eram capazes de se dividir em duas porções, uma das quais proli $~$ feraria originando uma esquizogonia. Mas as figuras apresentadas pelos

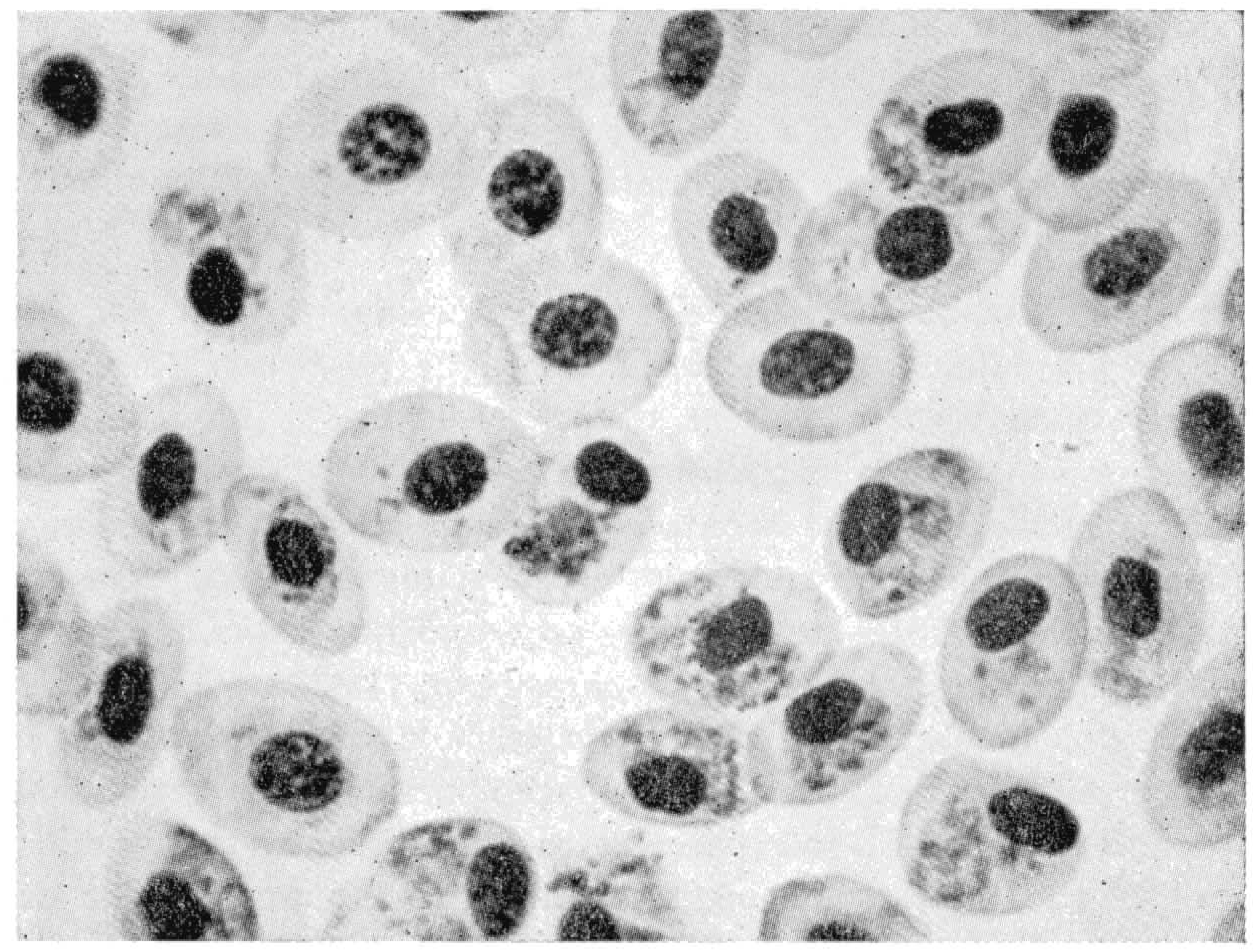

Fig. $7-P$. gallinaceum. Parasitos pigmentados nos glóbulos vermelhos. Infecção aguda. Apenas dois glóbulos indenes.

autores indicam de modo mais ou menos claro, quando existem, que se tratava da infecção de uma única hemácia por duas formas de parasitos, coisa que se observa com relativa freqüiência. Várias outras explicações foram tentadas. Entre as noções hoje prevalentes está a da quinino-resistência dos parasitos dos glóbulos vermelhos (NEIVA, 1910; WENYON, 1921, etc.). Depois de um tratamento, mesmo intensivo, ficam no organismo alguns parasitos residuais que evolvem tòrpidamente nas hemácias e cuja multiplicaşão lenta é controlada pelo mecanismo da resistência orgânica. Uma vez decaída 
esta, a multiplicação parasitária se acelera e atinge niveis elevados capazes de desencadear a sintomatologia da reca?da (Bignami, 1910; Ross, 1911).

De acôrdo com a doutrina exoeritrocitária a recaída tem uma explicação muito simples. Os parasitos que, depois da incubação, ficam evolvendo no retículo-endotélio, são capazes de aí permanecer por longo tempo, mesmo nos casos tratados, pois não são atacados pelos medicamentos usuais. De tempos a tempos êles são lançados na corrente circulatória, passando a evolver nas hemácias. Esta noção substitui vantajosamente a idéia da quininoresistência dos esquizontes pigmentados, além de explicar porque nos casos rebeldes ao tratamento a inoculação do sangue parasitado em indivíduo indene transmite a êste último uma infecção quase sempre tìpicamente sensível ao quinino. se bem que oriunda dos mesmos parasitos "resistentes" ao medicamento (TeIXEIRA, 1935).

Apoiando esta explicação para as recaídas encontra-se na bibliografia um caso de malária crônica, produzida pelo $P$. falciparum, no qual a volta dos parasitos foi tão violenta que provocou a morte da paciente. Neste caso encontraram-se as células endoteliais dos capilares do cérebro repletas de esquizogonias exoeritrocitárias (CAsINI, 1939).

Ainda não estão bem conhecidos os caracteres do ciclo exoeritrocitário nos plasmódios humanos. É preciso lembrar que êste ciclo apresenta certos aspectos particulares a cada espécie parasitária, como já ficou dito. Há plasmódios que dão esquizontes exoeritrocitários durante tôda a evolução da malária por êles causada, sempre em grande abundância. Outros formam êstes esquizontes apenas durante a incubação, derramando-os logo quase totalmente na circulação sanguínea, de modo a restar sòmente um número reduzidíssimo no retículo-endotélio. Os plasmódios humanos parecem entrar nesta última categoria (RAFFAELE, 1938b). O escasso número de parasitos exoeritrocitários residuais é compativel com a evolução tórpida própria à malária humana, a explica o fato de ser mais fàcilmente curável esta malária depois de várias recaídas do que nos primórdios da infecção, como foi fartamente comprovado por JAMES (1931).

Além desta escassez de formas endoteliais, concorre para dificultar o estudo do ciclo exoritrocitário no homem o grande volume das vísceras humanas em comparação com as das aves nas quais a malária tem sido bem estudada. Disso resulta uma concentração muito maior de parasitos no preparado microscópico de um cérebro de ave do que no de um cérebro humano. 
Leve-se ainda em conta a maior afluência de parasitos comumente observada no organismo das aves, que podem sobreviver a uma infecção de quase $100 \%$ das hemácias (fig. 7), ao passo que no homem essa taxa não é atingida porque a morte intervém com muita antecedência. A dispersão dos parasitos exoeritrocitários na massa enorme dos tecidos humanos torna difícil o encontro dêsses parasitos. Entretanto, êles já foram assinalados no periodo de incubação e na fase aguda da infecção, na medula óssea esternal de paralíticos gerais inoculados com esporozoitas de $P$. vivax (RAfFaele, 1937c; Tarsitano E LuCrezi, 1939), de P. falciparum (Raffaele, 1938a, 1940) e também de $P$. malariae (Raffaele, 1940). Foram encontrados ainda em casos de morte por malária, tanto aguda (PARAENSE E Silva, 1941; GaLVÃo, 1941) como crônica (CASINI, 1939). E interessante assinalar que nos casos necropsiados, todos vitimados pelo $P$. [alciparum, êles têm sido encontrados mais freqüentemente no cerebelo e em seguida no cérebro. Esta localização encefálica é a regra no $P$. gallinaceum e em certos tipos de $P$. cathemerium. Talvez uma pesquisa mais apurada dos elementos exeritrocitários nos casos mortais de malária humana, principalmente nos casos agudos intensamente tratados desde o início, resulte no encontro mais freqüente dêsses elementos. É fato verificado que nas aves a mortalidade por malária, assim como a resistência ao tratamento, coincidem com a existência de formas exoeritrocitárias, sendo provável que o mesmo aconteça no homem.

\section{REFERENCIAS}

AdLeR, S. E I. TChERNomoretz

1941. Continued passage of extra-erythrocytic forms of Plasmodium gallinaceum in the absence of erythrocytic schizogony. Ann. Trop. Med. Parasit. 35 (2): $241-246$.

Aragão, H. B.

1907. Sobre o cyclo evolutivo do halteridio do pombo. (Nota preliminar.) BrazilMedico 21 (15) : 141-142. (2. ${ }^{\mathrm{a}}$ nota) Ibid. 21 (31) : 301-303.

1908a. Über den Entwicklungsgang und die Übertragung von Haemoproteus columbae. Arch. Protistenk. 12 (1-2) : 154-167.

1908b. Sobre o ciclo evolutivo e a transmissão do Hemoproteus culumbae. Rev. Med. S. Panlo 11 (20) : 409-419.

BARRETo, M. P.

1943. Malaria aviaria. III. Sobre o encontro de formas exoeritrociticas do "Plasmodium juxtanucleare" Versiani e Gomes, 1941. Nota prévia. O Hospital 24 (5) : 643-645. 
Bignami, A.

1910. Sulla patogenesi delle recidive nelle febbri malariche. Atti Soc. Studi Mala ria 11 : 731-745.

BOYD, M, F.

1935. The comparative morphology of the sporozoites of the human species of Plasmodium, Marchiafava and Celli, 1885. Jour. Parasit. 21 (4) : 255-259.

Boyd, M. F. \& S. F. KitcheN

1939. The demonstration of sporozoites in human tissues. Amer. Jour. Trop. Med. 19 (1) : 27-31.

Boyd, M. F. E C. B. MatThEWS

1939. An observation on the incubation period of Plasmodium falciparum. Amer. Jour. Trop. Med. 19 (1) : 69-71.

Boyd, M. F. E W. K. Stratman-Thomas

1934. Studies on benign tertian malaria. 7. Some observations on inoculation and onset. Amer. Jour. Hyg. 20 (2) : 488-495.

BRUMPT, E.

1936. Précis de Parasitologie. 5. edição, Masson et Cie. Paris.

Casini, G.

1939. La fase apigmentata di evoluzione dei plasmodidi nella malaria cronica. Riv. Malariol. 18 (2) : 73-75.

ChORTIS, P.

1938. Su alcuni stadi di sviluppo del Plasmodium gallinaceum Brumpt, 1935. I. Nota. Riv. Parassit. 2 (2) : 121-128.

Ciuca, M., L. Ballif, M. Chelaresco, M. Isanos E L. Glaser

1937. Contributions à l'étude de la tierce maligne expérimentale. Pouvoir infectant du sang au cours de l'incubation. Riv. Malariol. 16 (2) : 85-90.

Corradetti, A.

1938. Alcune osservazioni sul ciclo schizogonico del Plasmodium gallinaceum e del Plasmodium cathemerium. Riv. Malariol. 17 (1) : 15-19.

Cuulston, F. E R. D. Manwell

1940. Single-parasite infections and exoerythrocytic schizogony in Plasmodium circumflexum. Jour. Parasit. 26 (6) suplemento : 27.

1941. Idem, idem. Amer. Jour. Hyg. 34 (2) Sec. C : 119-125.

Galvĩo, A.

1941. Sobre o encontro de formas apigmentadas de Plasmodium falciparum em celulas do sistema reticulo endotelial. Rev. Med. Cir. S. Paulo, 1 (4-6) : 158-159. 
Grassi, B.

1901. Die Malaria. Studien eines Zoologen. G. Fischer. Jena. Tradução do original italiano de 1900: Studi di un zoologo sulla malaria.

Hegner, R. E F WOLFSON

1938a. Toxoplasma-like parasites in canaries infected with Plasmodium. Amer. Jour. Hyg. 27 (1) : 212-220.

1938b. Association of Plasmodium and Toxoplasma-like parasites in hirds. Ibid. 28 (3) : 437-454.

1939. Tissue-culture studies of parasites in reticulo-endothelial cells in birds infected with Plasmodium. Ibid. 29 (2) Sec. C : 83-87.

Hewitt, R.

1940. Bird Malaria. The Johns Hopkins Press, Baltimore.

Hufr, C. G. $\mathcal{E}$ W. Bıоoм

1935. A malarial parasite infecting all blood and blood forming cells of birds. Jour. Infect. Dis. 57 (3) : 315-336.

Iyer, P. V. S., H. E. Shortt \& K. P. Menon

1941. The stage of Plasmodium gallinacerm found in the incubation period. Second observation. Jour. Malaria Inst. India 4 (2) : 179-180.

James, S. P.

1931. Some general results of a study of induced malaria in England. Trans. Roy. Soc. Trop. Med. Hyg. 24 (5) : 477-538.

1939. The incidence of exo-erythrocytic schizogony in Plasmodium gallinaceum in relation to the mode of infection. Ibid. 32 (6) : 763-769.

James, S. P. E P. Tate

1937a. New kncfwledge of the life-cycle of malaria parasites. Nature (Londres) 139 (3517) : 545.

1937b. Preparations illustrating the recently discovered cycle of avian malaria parasites in reticulo-endothelial cells. Trans. Roy. Soc. Trop. Med. Hyg. 31 (1) : 4-5.

KIKuTH, W.

1935. L'immunologie expérimentale et la chimiothérapie du paludisme. Riv. Malariol. 14 (6) Suplemento : 71-80.

1937. Endotheliale Schizogonie bei Hühnermalaria (Pl. gallinaceum, E. Brumpt 1935). Zentralbl. Bakter. I. Abt. Orig. 140 (3-8) : 227-229.

KikuTh, W. \& L. Mudrow

1937. Über pigmentlose Schizogonieformen bei Vogelmalaria. Klin. Wochenschr. 16 (48) : 1690-1691.

1938a. Malariaübertragungsversuche mit Blut und Organen sporozoiteninfizierter Kanarienvögel. Riv. Malariol. 17 (1) : 1-14. 
1938b. Die endothelialen Stadien der Malariaparasiten in Experiment und Theorie. Zentralbl. Bakter. I. Abt. Orig. 142 (3-4): 113-132.

1940. Die Umwandlung der Sporozoiten in die endotheliale Phase der Malariaparasiten. Riv. Malariol. 19 (1) : 1-15.

Manwell, R. D. E F. Goldstein

1938. Exoerythrocytic stages in the development of Plasmodium circumflexum and a comparison of these stages with Toxoplasma. Jour. Parasit. 24 (suplemento) : 21-22.

1939. Exoerythrocytic stages in the asexual cycle of Plasmodium circumflexum. Amer. Jour. Trop. Med. 19 (3) : 279-295.

Marchiafava, E. E A. Bignami

1931. La infezione malarica. 2. ${ }^{n}$ edição. F. Vallardi. Milão.

Maurer, G.

1902. Die Malaria perniciosa. Beitrag zur Biologie und Morphologie ihres Erregers.

Centralbl. Bakter. I. Abt. Orig. 32 (10) : 695-719.

Missiroli, A.

1933. Ricerche sullo sviluppo dei parassiti malarigeni. Nota preventiva. Riv. Malariol. 12 (5) : 985-986.

1934. Sullo sviluppo dei parassiti malarici. Nota $2 .^{n}$ Ibid. 13 (5) : 539-552.

1937. Sullo sviluppo dei parassiti malarici. III. Nota. Ibid. 16 (2) : 99-107.

Mudrow, L.

1940. Klinische und parasitologische Befuncle und chemotherapeutische Ergebnisse bei der Hühnermalaria. Arch. Schiffs- Trop. Hyg. 44 (6) : 257-275. Não foi visto o original. Resumo em Trop. Dts. Bull. 1943, 40 (2) : 116-117.

Neiva, A.

1910. Formação de raça do hematozoario do impaludismo rezistente á quinina. Mem. Inst. O. Cruz 2 (1) : 131-140.

Paraense, L.

1943. Aspectos parasitários observados no local inoculado com esporozoitos de Plasmodium gallinaceum. Nota preliminar. Mem. Inst. O. Cruz 38 (3) : 353-359.

Paraense, L. E E. M. Silva

1941. Esquizogonia exoeritrocitária do "Plasmodium falciparum". O Hospital 20 (1) : 99-106.

Piitaluga, G.

1903. Partenogenesi dei macrogameti di una varietà di Laverania (Laverania malariae var. mitis). (Osservazioni sulle forme della infezione malarica nella provincia di Barcelona). Arch. Parasit. 7 (3) : 389-397. 
RAFFAELE, G.

1934a. Sul comportamento degli sporozoiti nel sangue dell'ospite. Riv. Malariol. 13 (4) : 395-403.

1934b. Sul comportamento degli sporozoiti nel sangue dell'ospite. Nota II ${ }^{\mathrm{a}}$. Ibid. 13 (6) : 705-706.

1936a. Potere infettante del sangue durante l'incubazione della malaria aviaria. Ibid. 15 (2) : 77-87.

1936b. Il doppio ciclo schizogonico di Plasmodium elongatum. Ibid. 15 (5) : 309-317.

1936c. Presumibili forme iniziali di evoluzione di Plasmodium relictum. (Nota preventiva). Ibid. 15 (5) : 318-324.

1937a. Ancora sul ciclo schizogonico di Plasmodium elongatum. Ibid. 16 (1) : 79-83.

1937b. Sullo sviluppo iniziale dei parassiti malarici nell'ospite vertebrato. Ibid. 16 (3) : 185-198.

1937c. Ricerche sul ciclo di evoluzione iniziale dei parassiti malarici umani. Ibid. 16 (6) : 413-418.

1938a. Evoluzione di Plasmodium, Toxoplasma ed altri microrganismi regli organi interni dei vertebrati. Ibid. 17 (2) : 85-100.

1938b. La fase primaria dell'evoluzione monogonica dei parassiti malarici. Ibid. 17 (5) : 331-343.

1940. Ulteriori ricerche sulla fase monogonica primaria dei plasmodidi nell'uomo e negli uccelli. Ibid. 19 (4) : 193-225. Não foi visto o original. Resumo cm Trop. Dis. Bull. 1942, 39 (4) : 263.

Reichenow, E. E L. Mudrow

1943. Der Entwicklungsgang von Plasmodium praecox in Vogelkörper. Deut. Tropenmed. Ztschr. 47 (12) : 289-299. Não foi visto o original. Resumo em Trop. Dis. Bull. 1944, 41 (3) : 190-191.

Ross, R.

1911. The prevention of malaria. 2." edição. John Murray. Londres.

RUIGE, $\mathrm{R}$

1901. Untersuchungen über das deutsche Proteosoma. Centralbl. Bakter. 29 (5) : $187-191$.

SCHAUdinN, F.

1903. Studien über krankheitserregende Protozoen. II. Plasmodium vivax (Grassi $\mathcal{E}$ Feletti) der Erreger des Tertianfiebers beim Menschen. Arb. Kaiserl. Gesundhtsmt. $19: 169-250$.

\section{SchulemanN, W.}

1942. Zur Weiterentwicklung der Malariasporozoiten im Warmblüter. Deut. Med. Wochen. 68 (15) : 374-375. Não foi visto o original. Resumo em Trop. Dis. Bull. 1942, 39 (11) : 743.

Shortt, H. E., K. P. Menon \& P. V. S. Iyer

1940. The form of Plasmodium gallinaceum present in the incubation period of the infection. Ind. Jour. Med. Res. 28 (1) : 273-276. 
SiMPSON, M. L.

1944. Exoerythrocytic stages of Plasmodium durae. Journ. Parasit. 30 (3) : 177 178.

Tarsitano, A. E G. Lucrezi

1939. Reperti di forme apigmentate del parassita malarico. Arch. Ital. Sci. Med. Colon. Parassit. 20 (2) : 65-69.

TeIXeIRA, J. C.

1935. Quinino-resistencia na malaria. Considerações sobre o mechanismo de acção da quinina. O Hospital 7 (11) : 1151-1160.

Trompson, P. E. E C. G. HufF

1944. A saurian malarial parasite, Plasmodium mexicanum, n. sp., with both elongatum- and gallinaceum-types of exoerythrocytic stages. Jour. Infect. Dis. 74 (1) : 48-67.

Warren, A. J. E L. T. Coggeshall

1937. Infectivity of blood and organs in canaries after inoculation with sporozoites. Amer. Jour. Hyg. 26 (1) : 1-10.

WENYON, C. M.

1921. Part I. The incidence and aetiology of malaria in Macedonia. Jout. Roy. Army Med. Corps 37 (2) : 83-108.

YORKE, W.

1931. Comunicação pessoal na Discussão do trabalho de James (1931, pág. 527). ZiEMANN, $\mathrm{H}$.

1906. Capitulo Malaria, no tratado de C. Mense : Handbuch der Tropenkrankheiten (3. vol.), J. A. Barth, Leipzig. 